Asia Proceedings of Social Sciences

(APSS)

www.readersinsight.net/APSS

\title{
Does Strategic Location Strengthen the Relationship between Service Quality, Customer Satisfaction and Customer Loyalty?
}

\author{
Arawati Agus * \\ Graduate School of Business (UKM-GSB), Universiti Kebangsaan Malaysia, \\ Bangi, Selangor, Malaysia.
}

*Corresponding author's Email:araa@ukm.edu.my

Peer-review under responsibility of $4^{\text {th }}$ Asia International Conference 2018 editorial board (http://www.utm.my/asia/our-team/) (C) 2018 Published by Readers Insight Publisher, lat 306 Savoy Residencia, Block 3 F11/1,44000 Islamabad. Pakistan, info@ readersinsight.net 


\section{Research High Iight s}

This study investigates the relationships between service quality determinants namely tangible, reliability, responsiveness, competency, courtesy and credibility, with customer satisfaction and loyalty in the context of Malaysian hypermarkets. The paper also investigates the mediating role of customer satisfaction and also determines whether location (from the strategic perspective) plays a significant moderating role in the customer satisfactioncustomer loyalty linkage. The findings suggest that service quality has significant relationships with customer satisfaction and customer loyalty measures. The result indicates that three service quality determinants specifically tangibles, courtesy and credibility demonstrate high associations with customer satisfaction and customer loyalty. The result suggests that customer satisfaction has significant mediating role in the relationship between service quality and customer loyalty. In addition, location moderates the linkage between customer satisfaction and customer loyalty in both directions. The findings suggest that a more strategic location of a hypermarket can strengthen the relationship between customer satisfaction and customer loyalty.

\section{Graphical A bstract}

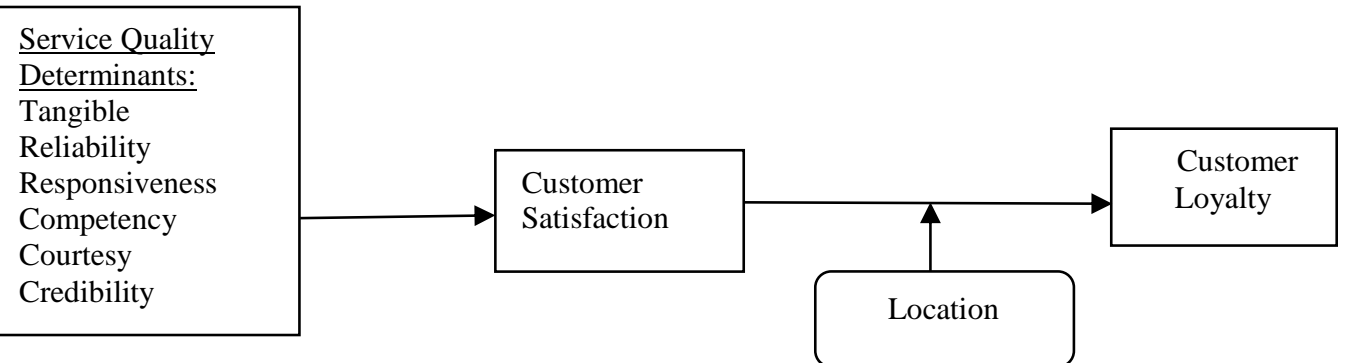

Figure 1. The conceptual model showing the relationship between service quality, customer satisfaction and customer loyalty with the moderating effect of location.

\section{Research Objectives}

One of the main motivations of the present research is to clarify the contradictory evidence with respect to the relationships between service quality, customer satisfaction, and loyalty, 


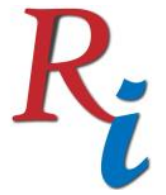

\section{Asia Proceedings of Social Sciences \\ (APSS) \\ www.readersinsight.net/APSS}

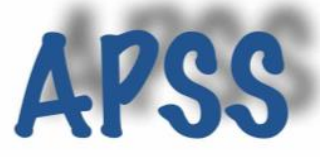

and to provide evidence of the mediating role of customer satisfaction and moderating role of location. In addition, no study, especially in Malaysia hypermarket context has investigated the moderating role of location on the linkage between customer satisfaction and customer loyalty, though a large body of knowledge on the concept of service quality does exist. Therefore, this study will address the issues by investigating the importance of service quality towards customer satisfaction and loyalty; the mediating role of customer satisfaction and the moderating role of location from the strategic perspective of the hypermarket sites. Specifically, the main objectives of this paper are:

1. To empirically discover whether service quality has significant impacts on customer satisfaction and customer loyalty.

2. To empirically investigate whether customer satisfaction has a mediating effect in the relationship between service quality and customer loyalty.

3. To empirically determine whether location has a moderating effect on the linkage between customer satisfaction and customer loyalty.

\section{Methodology}

The study adopted a quantitative, cross-sectional research method utilizing primary data collection. Due to the limitation of the non-existent sampling frame for this type of research, the study adopted a non-probability sampling method. The sample respondents in the study were individual customers of major hypermarkets in Klang Valley, Malaysia. The study was aimed at assessing the relationships between service quality, customer satisfaction and loyalty in the context of the Malaysian hypermarkets. The instrument developed in this study was a structured survey questionnaire, which was designed to assess the service quality of the hypermarkets in term of the described service quality dimensions. Several items of service quality, which had been widely referred and extracted were used in the research instrument (Parasuraman et al., 1985; Gronroos, 1984; Rust and Oliver; 1994). Similarly, the mediating, moderating, dependent constructs namely customer satisfaction, location and customer loyalty respectively were also measured using a seven-point interval scale. Two hundred and five responses were received and analysed. Face to face interviews with the customers were conducted to ensure the information accuracy, validating the outcome of analysis and developing an understanding of practical aspects of service quality dimensions. 


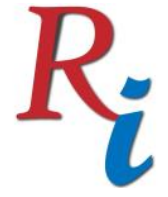

\author{
Asia Proceedings of Social Sciences \\ (APSS) \\ www.readersinsight.net/APSS
}

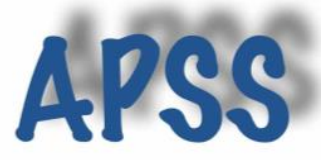

\title{
Results
}

Hierarchical regression analyses were conducted to investigate whether service quality determinants had significant influences and whether location moderated the linkage between customer satisfaction and customer loyalty. The dependent variable was regressed on the independent, moderator and the cross products of both variables (Snell and Dean, 1992, Agus and Iteng, 2013). In the first step, the predictor variable (customer satisfaction) with other service quality variables controlled, were entered into the regression equation with customer loyalty as the dependent variable. In the second step, the moderator variable (location) was entered into the equation. In the final step, the cross-product of the predictor variable (customer satisfaction) and the moderating variable (location) was entered. The result indicated that the interaction effect was significant (beta $=0.121, \mathrm{p}$-value $=0.013$ ). The simple slope indicated that the linkage between customer satisfaction and customer loyalty was significant both ways, when the location level was high (simple slope $=0.558, \mathrm{p}<.01$ ), and low (simple slope $=0.512, \mathrm{p}<.01$ ). Thus, the hypothesis was supported which proposed that location moderated the linkage between customer satisfaction and customer loyalty, such that the relationship became stronger when the location exhibited a higher strategic level and became weaker when the location was less strategic.

\section{Findings}

The findings suggest service quality has positive associations with customer performances; and customer satisfaction mediates the relationship between service quality and customer loyalty. Location plays a significant moderating role in how customer satisfaction leads to customer loyalty. The linkage between customer satisfaction and customer loyalty is strengthened or enhanced when location is strategically high and significantly dampens when strategic location level is low. In the future, the management of a hypermarket should choose a strategic location for the establishment of their business. In today challenging business environment, the effective implementation of service quality is critical for the survival and success of Malaysian hypermarkets. 


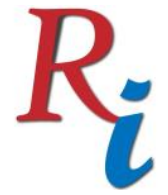

Asia Proceedings of Social Sciences

(APSS)

www.readersinsight.net/APSS

\section{References}

Agus, A. and Iteng, R. (2013). Lean Production and Business Performance: The Moderating Effect Of The Length Of Lean, Journal of Economics, Business and Management, 1(4),324-328.

Gronroos, C. (1984) A service Quality Model and Its Marketing Implications, European Journal of Marketing, 18(4), 36-44

Parasuraman, A., Zeithaml, W. and Berry, L. (1985). A conceptual model of service quality and its implications for future research. Journal of Marketing. 49, 41-50.

Rust, R. T. and Oliver, R. L. (1994). Service Quality: New directions in theory and practices. Sage publications, Thousand Oaks, California.

Snell, S.A., and Dean, J. W. (1992). Integrated manufacturing and human resource management: A human capital perspective. Academy of Management Journal. 35(30), 467-504. 